\title{
Adolescent Girls Empowerment Program (AGEP): Financial literacy and savings-Two-year follow-up
}

\author{
Karen Austrian \\ Population Council \\ Erica Soler-Hampejsek \\ Natalie Jackson Hachonda \\ Population Council \\ Paul C. Hewett \\ Population Council
}

Follow this and additional works at: https://knowledgecommons.popcouncil.org/departments_sbsr-pgy

Part of the Demography, Population, and Ecology Commons, Family, Life Course, and Society Commons, International Public Health Commons, and the Maternal and Child Health Commons How does access to this work benefit you? Let us know!

\section{Recommended Citation}

Austrian, Karen, Erica Soler-Hampejsek, Natalie Jackson Hachonda, and Paul C. Hewett. 2018. "Adolescent Girls Empowerment Program (AGEP): Financial literacy and savings-Two-year follow-up," brief. Lusaka: Population Council. 
Providing girls access to formal savings products has the potential to instill a culture of savings at a young age and develop positive money-management skills. This allows girls to build their own economic assets and, in turn, provide for themselves, manage emergencies, and help make safer and healthier decisions. ${ }^{1}$ Providing opportunities for girls to improve their financial literacy-including budgeting and moneymanagement skills-helps them plan their spending and develop a future orientation vis-à-vis money. ${ }^{2}$ Having a savings account can solidify the financial-literacy skills girls develop by providing concrete opportunities to put their financial-literacy skills to use..$^{3,4}$ Expanding adolescents' access to formal financial services also complements Zambia's national goals of financial inclusion. ${ }^{5}$

Lack of financial resources has been identified as a key driver of teenage pregnancy, which is linked to many other negative outcomes, such as early marriage and early school dropout. ${ }^{6,7}$ Therefore, for both economic and health reasons, working with girls to save as well as to be aware of the risks of depending on others for money, is not only an economic-strengthening intervention but also has the potential for a longer-term effect on sexual behavior and health outcomes.

\section{ADOLESCENT GIRLS EMPOWERMENT PROGRAM (AGEP)}

Through AGEP, the Population Council and partners implemented a social, health, and economic asset-building program in Zambia for over 11,000 vulnerable adolescent girls aged 10-19 years. The AGEP intervention was comprised of three major components: 1) weekly safe spaces groups in which girls met once a week for two years for training on sexual and reproductive health, life skills, and financial education; 2) a health voucher that girls could use at contracted private and public facilities for general wellness and sexual and reproductive health services; and 3) a savings account that was designed by the National Savings and Credit Bank of Zambia (Natsave) specifically to be girl-friendly.

The Population Council worked in partnership with NatSave, a Zambian parastatal financial institution, and Making Cents International (MCl), a Washington, DC-based consulting firm with expertise in providing technical assistance on youth-friendly financial product development, to develop a bank account specifically tailored to the needs of young girls in Zambia. The account had a small opening-balance requirement, no monthly fees, and a simplified account-opening process that allowed girls under the age of 18 to open, own, and make transactions on their account. ${ }^{a}$

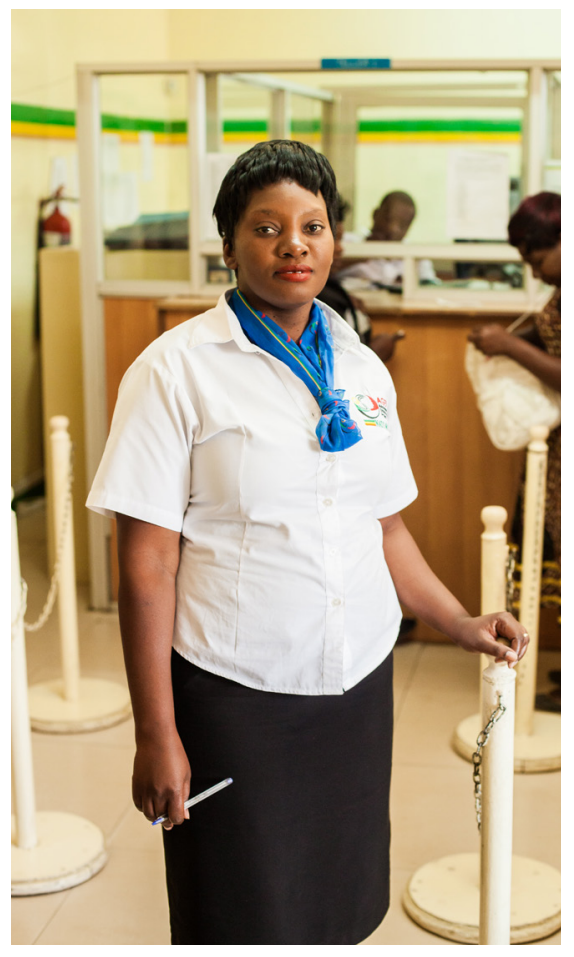

${ }^{a}$ A waiver was obtained from the Bank of Zambia to allow minors to operate an account. An adult cosigner was required for account opening and withdrawals. 


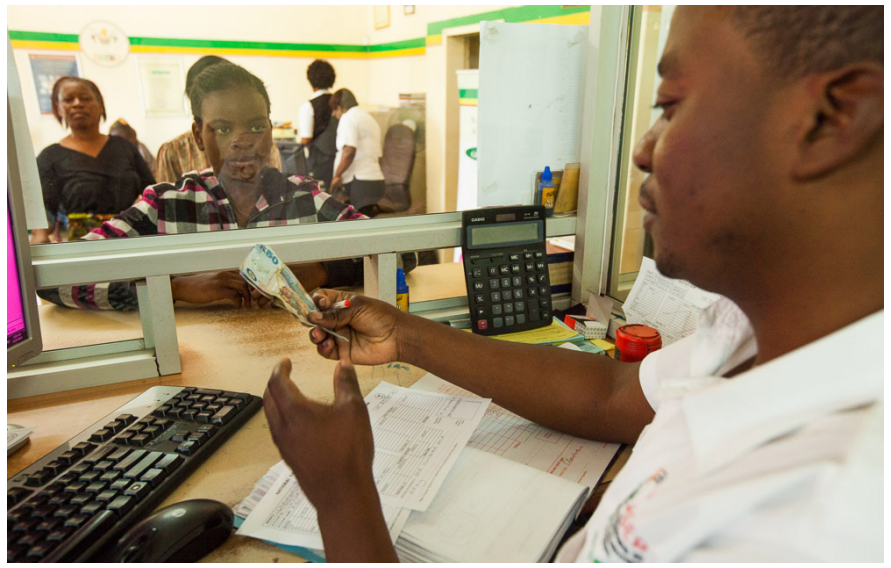

A randomized controlled trial (RCT) completed in 2017 evaluated the impact of AGEP on financial literacy and savings behaviors. Communities where AGEP was being implemented were randomly assigned different versions of the intervention-including safe spaces only, safe spaces with health vouchers, and the full program (safe spaces, health vouchers, and savings accounts). In the control group, girls received no intervention. Data collected in 2015 represents the results of the program at the end of the two-year intervention. An initial savings brief ${ }^{b}$ described the process and lessons learned from the development of the account, as well as the short-term effect on financial literacy and savings behavior. Overall, AGEP successfully improved girls' financial literacy and savings behavior, and the results were strongest for those with a savings account. This brief focuses on those indicators two years after the program ended and reflects on the implications for the financial-services field in Zambia.

\section{RESULTS}

\section{Account usage}

Between January 2016 and December 2017, representing the two years after the program ended, girls were still using their "Girls Dream" savings accounts, although less frequently than during the intervention period. During the course of the two-year program, about $30 \%$ of the 2,094 girls who had opened accounts made additional transactions during the intervention period. In the two-year period following the program, only $5 \%$ of girls transacted on their account, although for those that did transact, they did so on average between three and four times per girl. Long-term account usage is depicted in Table 1, below.

\section{Savings and financial literacy outcomes}

Short-term program results indicated a positive impact on girls' financial literacy scores, as well as the frequency and amount of their savings. These effects were stronger for girls who opened savings accounts. Looking at the longer-term, post-intervention impact of AGEP on financial literacy outcomes, we see that the difference between the program and control girls' financial literacy scores did not remain, but the improved savings behavior did. Girls who participated in AGEP were seven percentage points more likely to have saved in the past year, and for girls who participated in more than half of the safe spaces sessions, that goes up to nineteen percentage points. For girls who opened savings accounts, the effect on saving is even stronger, with a thirty-one percentage point difference. In addition, girls with savings accounts had long-term increases in self-efficacy, more than double those of girls in the program without savings accounts.

\section{CONCLUSION}

The Adolescent Girls Empowerment Program-through its financial literacy curriculum and the developing and opening of savings accounts for program beneficiaries-was successful in initially strengthening girls' money-management skills-budgeting, financial goal-setting, and savings-as well as their savings behavior-both frequency and amount. Two years after girls stopped receiving regular financial-education training, the financial-literacy score for beneficiaries was no longer higher than the control group, but the improved savings behavior remained. This indicates that AGEP had set participants on the path of long-term regular savings behavior. In addition, savings accounts remained a motivation for savings behavior-whether formal or informal-even two years after the financial-literacy and regular group meetings ended.

TABLE 1. ACCOUNT USAGE BETWEEN 2016 AND 2017, TWO YEARS AFTER THE PROGRAM ENDED

\begin{tabular}{|c|c|c|}
\hline & Deposits & Withdrawals \\
\hline Total number of transactions ${ }^{c}$ & 202 & 169 \\
\hline Total volume $(Z M W)^{d}$ & 79,040 & 80,581 \\
\hline Mean amount (ZMW) per transaction & 391 & 477 \\
\hline Median amount (ZMW) per transaction & 50 & 100 \\
\hline
\end{tabular}


- $\quad$ AGEP included a 19-session financial-education curric ulum that was delivered in a group-based setting by a female mentor.

- $\quad$ AGEP, working with the National Savings and Credit Bank (Natsave) to design an adolescent-friendly savings account, helped program participants open a savings account at the nearest Natsave branch.

- The AGEP program had positive short-term effects on financial literacy and both short- and long-term effects on savings behavior.

- The savings account catalyzed positive savings behavior-both formal and informal-and had positive effects on girls' self-efficacy.

\section{RECOMMENDATIONS}

Given the financial literacy and savings results from AGEP, we recommend the following:

- $\quad$ Financial literacy for adolescents should be integrated into both health and life skills, as well as economic empowerment programs.

- Adolescent-friendly savings accounts should be made more widely available by financial institutions in Zambia, including features such as very low opening-balance requirements, no monthly fees or transaction charges, and simple "know your customer" and account-opening requirements.

- Banking regulations should allow adolescents to operate accounts in their own name, and require a cosigner only for account opening and withdrawals.

- $\quad$ Financial institutions should make depositing and withdrawing easier by using digital technologies and placing banking services within communities (especially in rural areas). In cases where those services exist, regulations should allow adolescents to use these methods of transacting.

\section{REFERENCES}

1. Karimli, L. and F.M. Ssewamala. 2015. "Do savings mediate changes in adolescents' future orientation and health-related outcomes? Findings from randomized experiment in Uganda," Journal of Adolescent Health 57(4): 425-432.

2. Xu, L. and B. Zia. 2013. "Financial literacy in the developing world."

3. Fernandes, D., J.G. Lynch Jr., and R.G. Netemeyer. 2014. "Financial literacy, financial education, and downstream financial behaviors," Management Science 60(8): 1861-1883.

4. Miller, M., J. Reichelstein, C. Salas, and B. Zia. 2014. "Can you help someone become financially capable? A meta-analysis of the literature." Policy Research Working Paper No. 6745. Washington, DC: World Bank.

5. Republic of Zambia. 2017. "National Financial Inclusion Strategy: 2017-2022.” Ministry of Finance, Zambia.

6. Mathur, S., M. Greene, and A. Malhotra. 2003. “Too Young to Wed: The Lives, Rights and Health of Young Married Girls." International Center for Research on Women.

7. UNICEF. 2014. "Ending Child Marriage: Progress and Prospects.” New York: UNICEF.

Authors: Karen Austrian, Erica Soler-Hampejsek, Natalie Jackson Hachonda, and Paul C. Hewett. 


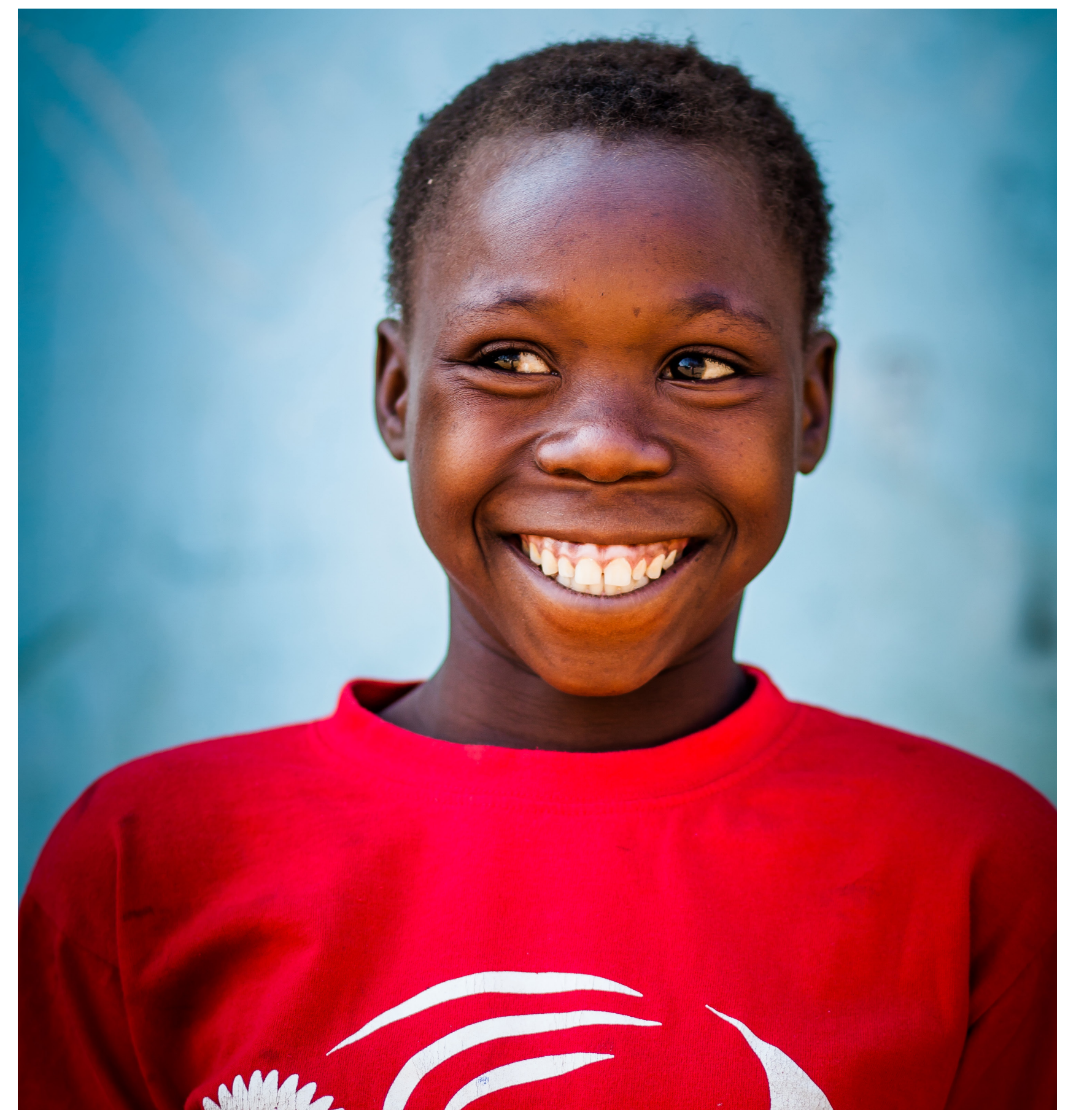

\section{CONTACT INFORMATION}

For more information about AGEP, call +260 211295925

or email: info@popcouncil.org

or visit: http://www.popcouncil.org/research/

adolescent-girls-empowerment-program
Population Council

Plot \#3670 No. 4 Mwaleshi Road

Olympic Park

Lusaka, Zambia 10101 